\title{
Soil and vegetation carbon stocks in Brazilian Western Amazonia: relationships and ecological implications for natural landscapes
}

\author{
C. E. G. R. Schaefer • E. F. do Amaral • \\ B. A. F. de Mendonça • H. Oliveira • J. L. Lani • \\ L. M. Costa • E. I. Fernandes Filho
}

Received: 8 November 2006 / Accepted: 3 July 2007 /Published online: 11 September 2007

(C) Springer Science + Business Media B.V. 2007

\begin{abstract}
The relationships between soils attributes, soil carbon stocks and vegetation carbon stocks are poorly know in Amazonia, even at regional scale. In this paper, we used the large and reliable soil database from Western Amazonia obtained from the RADAMBRASIL project and recent estimates of vegetation biomass to investigate some environmental relationships, quantifying $\mathrm{C}$ stocks of intact ecosystem in Western Amazonia. The results allowed separating the western Amazonia into 6 sectors, called pedo-zones: Roraima, Rio Negro Basin, Tertiary Plateaux of the Amazon, Javari-JuruáPurus lowland, Acre Basin and Rondonia uplands. The highest $\mathrm{C}$ stock for the whole soil is observed in the Acre and in the Rio Negro sectors. In the former, this is due to the high nutrient status and high clay activity, whereas in the latter, it is attributed to a downward carbon movement attributed to widespread podzolization and arenization, forming spodic horizons. The youthful nature of shallow soils of the Javari-JuruáPurus lowlands, associated with high $\mathrm{Al}$, results in a high phytomass $\mathrm{C} /$ soil $\mathrm{C}$ ratio. A similar trend was observed for the shallow soils from the Roraima and Rondonia highlands. A consistent east-west decline in
\end{abstract}

C. E. G. R. Schaefer $(\bowtie) \cdot$ E. F. do Amaral

B. A. F. de Mendonça $\cdot$ H. Oliveira $\cdot$ J. L. Lani •

L. M. Costa $\cdot$ E. I. Fernandes Filho

Departamento de Solos, Universidade Federal de Viçosa,

36571-000 Viçosa, Minas Gerais, Brazil

e-mail: carlos.schaefer@ufv.br biomass carbon in the Rio Negro Basin sector is associated with increasing rainfall and higher sand amounts. It is related to lesser $\mathrm{C}$ protection and greater C loss of sandy soils, subjected to active chemical leaching and widespread podzolization. Also, these soils possess lower cation exchangeable capacity and lower water retention capacity. Zones where deeply weathered Latosols dominate have a overall pattern of high $\mathrm{C}$ sequestration, and greater than the shallower soils from the upper Amazon, west of Madeira and Negro rivers. This was attributed to deeper incorporation of carbon in these clayey and highly pedo-bioturbated soils. The results highlight the urgent need for refining soil data at an appropriate scale for $\mathrm{C}$ stocks calculations purposes in Amazonia. There is a risk of misinterpreting $\mathrm{C}$ stocks in Amazonia when such great pedological variability is not taken into account.

Keywords Aboveground biomass · Soil carbon stocks . Western Amazonia soils

\section{Introduction}

The relationship between soil carbon stocks and carbon fixation in natural and anthropic vegetation remains one of the least studied issues in the understanding of the carbon cycle for terrestrial Amazonia. Emphasis has been placed on measurements of carbon fixation by secondary forests (Fearnside and Guimarães 1996) or 
measurements of carbon emissions following land-use changes (Fearnside 2000). Basically, the amount and quality of natural soil organic carbon is highly influenced by vegetation type and land use, as recently demonstrated by Andrade et al. (2004). Most studies on carbon stocks in aboveground vegetation do not consider the inherent soil constraints for allowing various rates of biomass production.

Biomass of intact vegetation, both forest and nonforest types, are important components for quantifying $\mathrm{C}$ pools and $\mathrm{C}$ dynamics in Amazon ecosystem (Cummings et al. 2002), although reliable information on total above ground biomass is scarce. Most available information is based on forest inventory data (Brown and Lugo 1992; Fearnside 1992; Brasil 2004) at different scales, as well as field measurements of forest trees (e.g.; Higuchi et al. 1994).

Recently, reliable field data based on forest structure was provided by Barbosa and Fearnside (1999) for north-western Amazonia, where a high diversity of vegetation types occur, and for forests of southwestern Amazonia (Cummings et al. 2002). These studies highlighted the wide range of biomass estimates for different vegetation types in western Amazonia.

On the other hand, a recent compilation of vegetation biomass for the entire Amazon region, based on the RADAMBRASIL forest inventory (Brasil 2004), has shown many inconsistencies, possibly due to lack of accuracy for some vegetation types, and overestimation of poorly-known non-forest vegetation.

The objective of the present paper was to model and interpret the available information on soil and biomass carbon stocks and the relationship between both, from a regional viewpoint, taking into account the ecological implications and trends in carbon dynamics in the whole ecosystem of western Amazonia.

\section{Material and methods}

Study area

The study area comprises the Western Amazonia region, encompassing the Brazilian states of Amazon, Acre, Rondônia and Roraima (Fig. 1). The soil cover is dominated by Latosols (Oxisols), Spodosols, Argisols (Ultisols) and Cambisols (Inceptsols), forming many different soil associations. Pedological data was based on regional soil surveys, using well-established ana- lytical data for carbon amounts (EMBRAPA 2007; Brasil 1975a, b, c, 1976a, b, c, 1977a, b, c, 1978a, b, c, 1979). The predominant vegetation types are dense and open lowlands and dense submontane ombrophilous forest.

Soil carbon stocks estimates

Soil carbon stocks were obtained from the large database of RADAMBRASIL and EMBRAPA, based on 347 complete soil profiles: 86 pedons from the Acre State (Brasil 1976a, 1977a), 129 pedons from Amazonas (Brasil 1975a, b, 1976a, b, c, 1977a, b, c, 1978a, b, c), 43 pedons from Rondonia (Brasil 1978c, 1979) and 89 pedons from Roraima (Brasil 1975b, c, 1978b). All analytical data were processed using ArcGIS 9.0 software for area calculation and map production. The original soil map had 706 polygons divided in 347 mapping units, according with the number of soil classes in each soil unit. Soils were classified according with the Brazilian System of Soil Classification (EMBRAPA 1999).

In order to simplify the overall calculations, some generalization was necessary and soils were grouped following the recommendations of Houghton et al. (1997), aimed at carbon stocks inventories, taking into account texture, clay activity, base saturation and soil moisture. For this procedure, mapping units were separated into six groups, with the following main components G1, luvisols and eutric argisols and eutric cambisols; G2, cambisols; G3, dystric argisols, aluminic argisols and nitosols; G4, other aluminic soils (formerly alisols); G5, gleysols, fluvic neosols (entisols) and plinthosols and G6, latosols and quartzarenic neosols.

Soil carbon stocks for each soil horizon $\left(\mathrm{CS}_{h}\right)$ were obtained by multiplying the carbon content, soil bulk density and depth of a given horizon (Eq. 1). For each diagnostic $\mathrm{A}$ and $\mathrm{B}$ horizon the carbon stocks for each soil profile $-\mathrm{CS}_{A}$ (Eq. 2) and $C S_{B}$ (Eq. 3), respectively - were calculated considering the total volume of each one, including the transitional horizons. The total Carbon Stocks (CS) was based on the sum of the whole profile (Eq. 4).

$\mathrm{CS}_{h}=C \times \mathrm{SD} \times h$

$\mathrm{CS}_{A}=\sum \mathrm{CS}_{h}$ 
Fig. 1 Western Amazonia and its location in Brazil and South America, with a total area of $2,195,921 \mathrm{~km}^{2}$ (1 Acre; 2 Amazonas; 3 Rondonia; 4 Roraima)

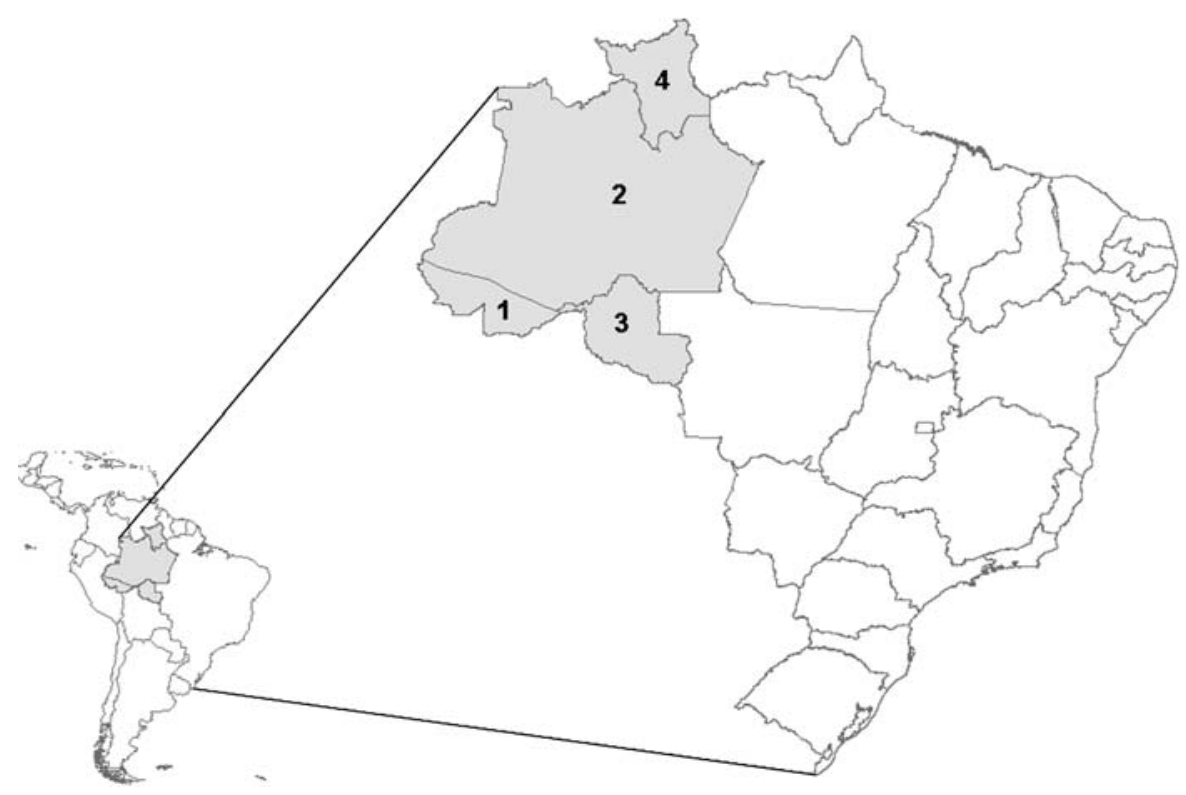

$\mathrm{CS}_{B}=\sum \mathrm{CS}_{h}$

$\mathrm{CS}_{p}=\sum_{B}^{A} \mathrm{CS}_{h}$

where:

CS Soil carbon stocks $\left(\mathrm{kg} \mathrm{m}^{-2}\right)$

C Carbon content [\% (weight/weight)]

SD Soil density $\left(\mathrm{g} \mathrm{cm}^{-3}\right)$

$h \quad$ Depth (m)

Whenever soil bulk density was not determined, we estimated their values through multilinear equations relating clay content, carbon content and $\mathrm{pH}$, obtained by representative soil data from the Amazon Basin (Bernoux 1998; Bernoux et al. 1998). For soil horizons with less than $20 \%$ clay, we used the following equation:

$$
\begin{aligned}
\mathrm{SD}= & 0.0181 \times(100-\mathrm{CC}-5)-0.08 \\
& \times \mathrm{OC}, r^{2} \\
= & 0.66
\end{aligned}
$$

In all remaining cases, the calculations were performed using specific equations for each soil group, as described below:

- G1, G2, G3, G4 groups:

$$
\begin{aligned}
\mathrm{SD}= & 1.394-(0.0051 \times \mathrm{CC}) \\
& -(0.307 \times \mathrm{OC}), r^{2} \\
= & 0.47
\end{aligned}
$$

- G5 group:

$$
\begin{aligned}
\mathrm{SD}= & 1.58-(0.0040 \times \mathrm{CC}) \\
& -(0.050 \times \mathrm{OC})-(0.047 \times \mathrm{pH}), r^{2} \\
= & 0.51
\end{aligned}
$$

- G6 group:

$$
\begin{aligned}
\mathrm{SD}= & 1.404-(0.0040 \times \mathrm{CC}) \\
& -(0.048 \times \mathrm{OC}), r^{2} \\
= & 0.71
\end{aligned}
$$

where:

CC Clay content following dispersion with $\mathrm{Na}$ hexametaphosphate [\% (weight/weight)] 
OC Organic carbon by Walkley and Black (1934) [\% (weight/weight)]

$\mathrm{pH} \quad \mathrm{pH}$ in water

\section{Soil carbon maps}

For the soil carbon map of Western Amazonia, we used the pondered mean of carbon stocks for each soil mapping unit, in each polygon, using ArcGIS 9.0.

Carbon stocks estimates of the main vegetation type for Western Amazonia

The present calculation outline made use of the vegetation classification adopted by Brazilian Institute of Geography and Statistic (IBGE 1988) for the 1:5,000,000 scale vegetation map. For calculation purposes, we quantified the mean carbon stocks $(\mathrm{Mg} / \mathrm{ha})$ for plant biomass (live and dead) for western Amazonia, encompassing the states of Acre, Amazonas, Roraima e Rondonia. Additionally, the official Brazilian Reference Report (Brasil 2004) and data published by Barbosa and Fearnside (1999) were also used for these estimates (Table 1).

\section{Vegetation map}

The distribution of the different vegetation types was based on the IBGE (1988) regional vegetation map, georeferenciated for the same cartographical basis.

Table 1 Carbon stocks in biomass for different vegetation types in Western Amazonia used in this work (modified from Barbosa and Fearnside 1999 and Brasil 2004)

\begin{tabular}{|c|c|c|c|}
\hline Legend & Vegetation type & $\begin{array}{l}\text { Carbon stocks } \\
(\mathrm{Mg} / \mathrm{ha})(\text { Brasil 2004) }\end{array}$ & $\begin{array}{l}\text { Carbon stocks }(\mathrm{Mg} / \mathrm{ha}) \\
\text { (Barbosa and Fearnside 1999) }\end{array}$ \\
\hline $\mathrm{A}$ & Anthropic area & - & - \\
\hline $\mathrm{Aa}$ & Alluvial open ombrophilous forest & 130.72 & 122.93 \\
\hline $\mathrm{Ab}$ & Lowland open ombrophilous forest & 107.45 & 123.34 \\
\hline As & Submontane open ombrophilous forest & 104.01 & 116.70 \\
\hline $\mathrm{D}$ & Anthropic area & - & - \\
\hline $\mathrm{Da}$ & Dense alluvial ombrophilous forest & 123.15 & 148.00 \\
\hline $\mathrm{Db}$ & Dense lowland ombrophilous forest & 122.81 & 148.50 \\
\hline $\mathrm{Dm}$ & Dense montane ombrophilous forest & 78.23 & 125.00 \\
\hline Ds & Dense submontane ombrophilous forest & 100.30 & 140.50 \\
\hline $\mathrm{F}$ & Anthropic area & - & - \\
\hline Fs & Semideciduous submontane forest & 152.93 & 121.50 \\
\hline LO & $\begin{array}{l}\text { Areas of ecological tension and contact: woody oligothrophic } \\
\text { vegetation of swampy and sandy areas/ombrophilous forest }\end{array}$ & 128.63 & 133.00 \\
\hline $\mathrm{La}$ & Open woody oligothrophic vegetation of swampy and sandy areas & 18.03 & 19.40 \\
\hline $\mathrm{Ld}$ & Dense woody oligothrophic vegetation of swampy and sandy areas & 134.46 & 23.80 \\
\hline $\mathrm{Lg}$ & $\begin{array}{l}\text { Woody grassland oligothrophic vegetation of swampy and sandy } \\
\text { areas }\end{array}$ & 125.46 & 4.75 \\
\hline $\mathrm{ON}$ & $\begin{array}{l}\text { Areas of ecological tension and contact: ombrophilous forest/ } \\
\text { semideciduous forest }\end{array}$ & 137.87 & 121.50 \\
\hline $\mathrm{Pa}$ & Pioneer vegetation & 111.31 & 16.65 \\
\hline $\mathrm{S}$ & Anthropic área & - & - \\
\hline $\mathrm{SN}$ & $\begin{array}{l}\text { Areas of ecological tension and contact: savanna/semideciduous } \\
\text { forest }\end{array}$ & 133.84 & 85.00 \\
\hline $\mathrm{SO}$ & Areas of ecological tension and contact: savanna/ombrophilous forest & 118.78 & 85.00 \\
\hline As & Open woody savanna & 15.39 & 3.00 \\
\hline $\mathrm{Sg}$ & Woody grassland savanna & 114.76 & 1.65 \\
\hline $\mathrm{Sp}$ & Savanna parkland & 107.08 & 3.00 \\
\hline $\mathrm{Td}$ & Dense steppe-like savanna & 114.76 & 14.50 \\
\hline $\mathrm{Tp}$ & Steppe-like savanna parkland & 107.08 & 2.80 \\
\hline $\mathrm{Rm}$ & Highland ecological refuge & 110.85 & 1.55 \\
\hline
\end{tabular}


According to this map, the vegetation types in Western Amazonia are listed in Table 1.

Calculation of the aboveground carbon stocks

The reference report published by the Brazilian Science and Technology Ministry shows estimates of emissions and sequestration of atmospheric $\mathrm{C}$ due to changing land uses. For ecotonal (ecological tension) areas, we have calculated the biomass as mean of the two contacting vegetation types. Biomass for Campinarana and Savana types, not measured in the field, were calculated by interpolation, correcting these values for fitting them within the existing range of tree-density values.

Barbosa and Fearnside (1999) presented (live and dead) aboveground biomass data for Roraima, according to the vegetation map of IBGE. Based on this work, carbon stocks in the vegetation types were calculated using conversion of $50 \%$ of $\mathrm{C}$ for biomass weight (Brown 1986; Montagnini and Porras 1998). For other western Amazonian forest types (Alluvial Open Forest, Lowland Forest and Semideciduous Submontane Forest) we have considered data published by Cummings et al. (2002) for southwestern Amazonian forest types (Fig. 2).
Due to a high heterogeneity of land use covers in Anthropic (replacement) areas, the biomass carbon stocks for these mapping units were not quantified. We considered that any values assumed for anthropic land uses would be, at best, a reasonable guess. Hence, only natural environments are calculated and mapped in this work, excluding the areas under anthropic influence (mapped as blank polygons) from the total area.

\section{Carbon stocks maps}

The maps of carbon stocks at the soil surface, subsurface, total soil and vegetation were overlain with rainfall data (INMET 2007), allowing interpretation of carbon behaviour following the regional climatic gradient, using the software ArcGIS 9.0.

The indexes associating carbon amounts in vegetation with soil carbon stocks (total, surface and subsurface), were obtained by dividing a given amount of carbon in the biomass for the value found at a given soil mapping unit. This was possible since soil and vegetation data were individually plotted, allowing these calculations in a simple and fast way, using Geography Information System. All maps were derived from these basic soil and vegetation carbon and rainfall data.

Fig. 2 Total carbon stocks in vegetation

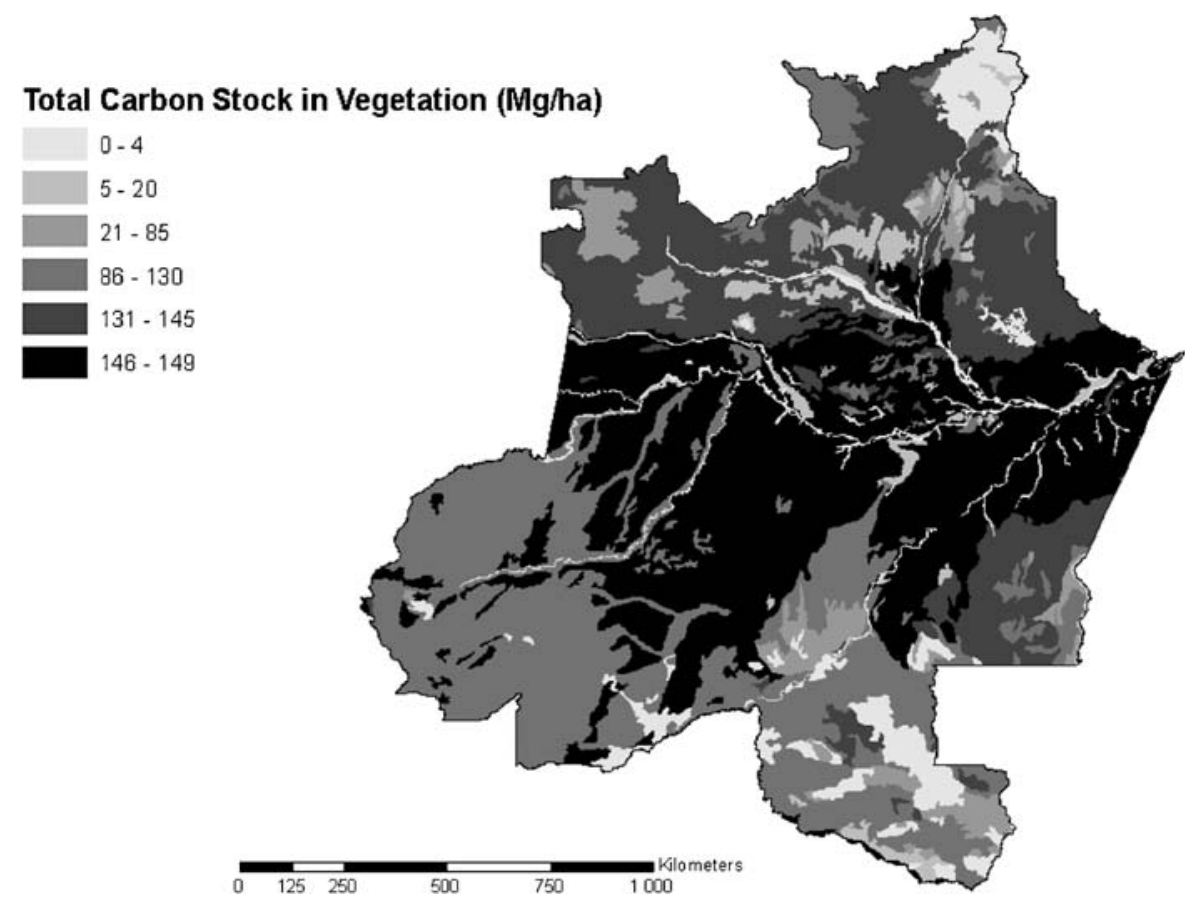


Fig. 3 The environmental sectors (pedo-zones) of Western Amazonia, based on geomorphological and pedological characteristics (see Table 2 for details)

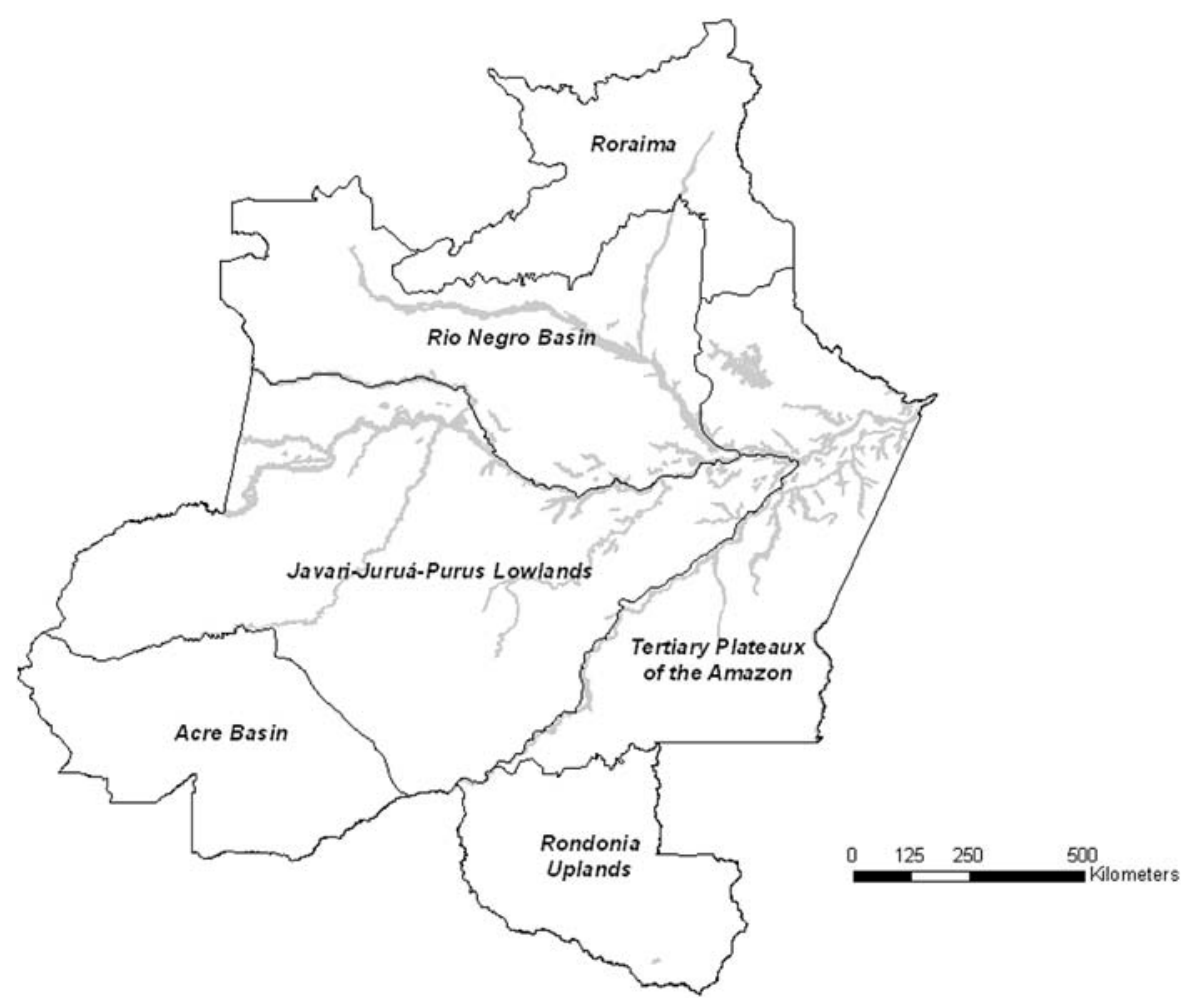

Total carbon stocks

The total C stocks in Western Amazonia soils (Fig. 4) reveals an interesting trend of higher total $\mathrm{C}$ stock in the Acre and in the Rio Negro basin pedo-zones, for two different reasons; (1) in the Negro basin, most C is being actually lost from the topsoil to the subsurface layers (spodic horizons) by podzolization and

Table 2 Summary of the main characteristics of the environmental sectors of Western Amazonia

\begin{tabular}{|c|c|c|c|}
\hline Zone or sector & Soils & Landforms and geology & $\begin{array}{l}\text { Relative } \\
\text { area } \\
(\%)\end{array}$ \\
\hline Acre basin & $\begin{array}{l}\text { Eutric cambisols; luvisols; eutric neosols (2:1 } \\
\text { clays) }\end{array}$ & $\begin{array}{l}\text { Gentle and undulating hills, flat alluvial plains; terraces } \\
\text { of } 2: 1 \text { clayey quaternary sediments }\end{array}$ & 10.95 \\
\hline $\begin{array}{l}\text { Javari-Juruá- } \\
\text { Purus } \\
\text { Lowlands }\end{array}$ & $\begin{array}{l}\text { Aluminic plinthosols, dystric gleysols, alisols; } \\
\text { dystric and aluminic argisols }\end{array}$ & $\begin{array}{l}\text { Gentle hills, alluvial plains of quartzose, acid } \\
\text { quaternary sediments }\end{array}$ & 31.73 \\
\hline $\begin{array}{l}\text { Rondonia } \\
\text { Uplands }\end{array}$ & Dystric argisols, latosols, nitosols & $\begin{array}{l}\text { Deeply dissected hills and tablelands on tertiary } \\
\text { sediments and crystalline rocks }\end{array}$ & 8.64 \\
\hline Roraima & $\begin{array}{l}\text { Dystric argisols, yellow latosols, dystric litholic } \\
\text { neosols, minor plinthosols and gleysols }\end{array}$ & $\begin{array}{l}\text { Variable: highly dissected to lowland flats and terraces; } \\
\text { crystalline rocks with quartzitic high plateaux }\end{array}$ & 11.54 \\
\hline Rio Negro basin & Quartzarenic neosol, hydromorphic spodosols & $\begin{array}{l}\text { Extensive waterlogged sandy plains on quaternary } \\
\text { sediments }\end{array}$ & 19.54 \\
\hline $\begin{array}{l}\text { Tertiary Plateaux } \\
\text { of the Amazon }\end{array}$ & $\begin{array}{l}\text { Yellow and red-yellow dystric latosols and } \\
\text { argisols }\end{array}$ & $\begin{array}{l}\text { Tablelands and gently dissected hills on tertiary } \\
\text { "Barreiras Group" sediments }\end{array}$ & 17.60 \\
\hline
\end{tabular}


Fig. 4 Total $\mathrm{C}$ stocks in

Western Amazonia soils

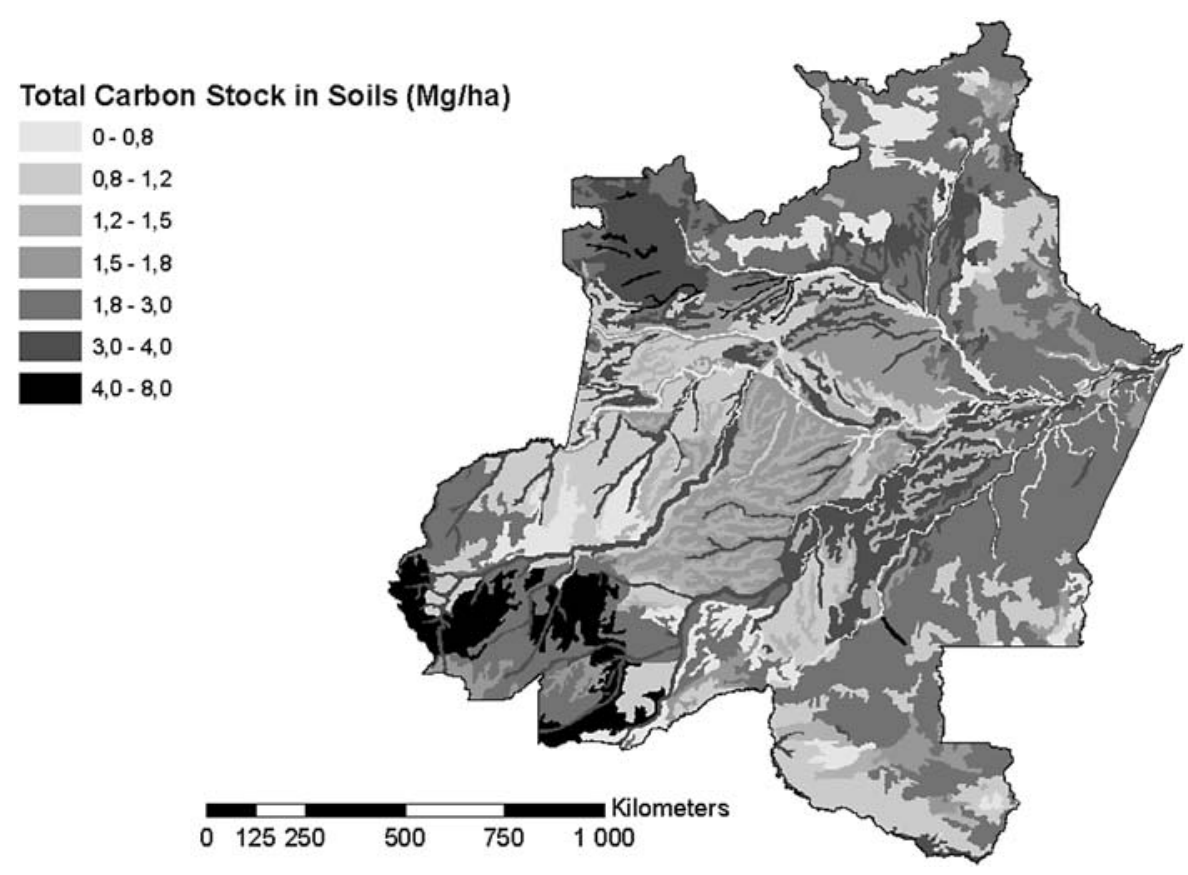

deep arenization, meaning active carbon losses due to low physical carbon protection in these sandy soils. (2) On the other hand, in the Acre sector higher carbon stocks values are influenced by high activity 2:1 clays of Andean origin, with high nutrient status than elsewhere in Amazonia, enhancing primary productivity.

The high $\mathrm{C}$ aboveground (shoot) biomass/C soil (Fig. 5) in the Javari-Juruá-Purus lowlands is a clear indication of the recent development of the Aluminic
Fig. 5 The $\mathrm{C}$ phytomass/C soil in Western Amazonia

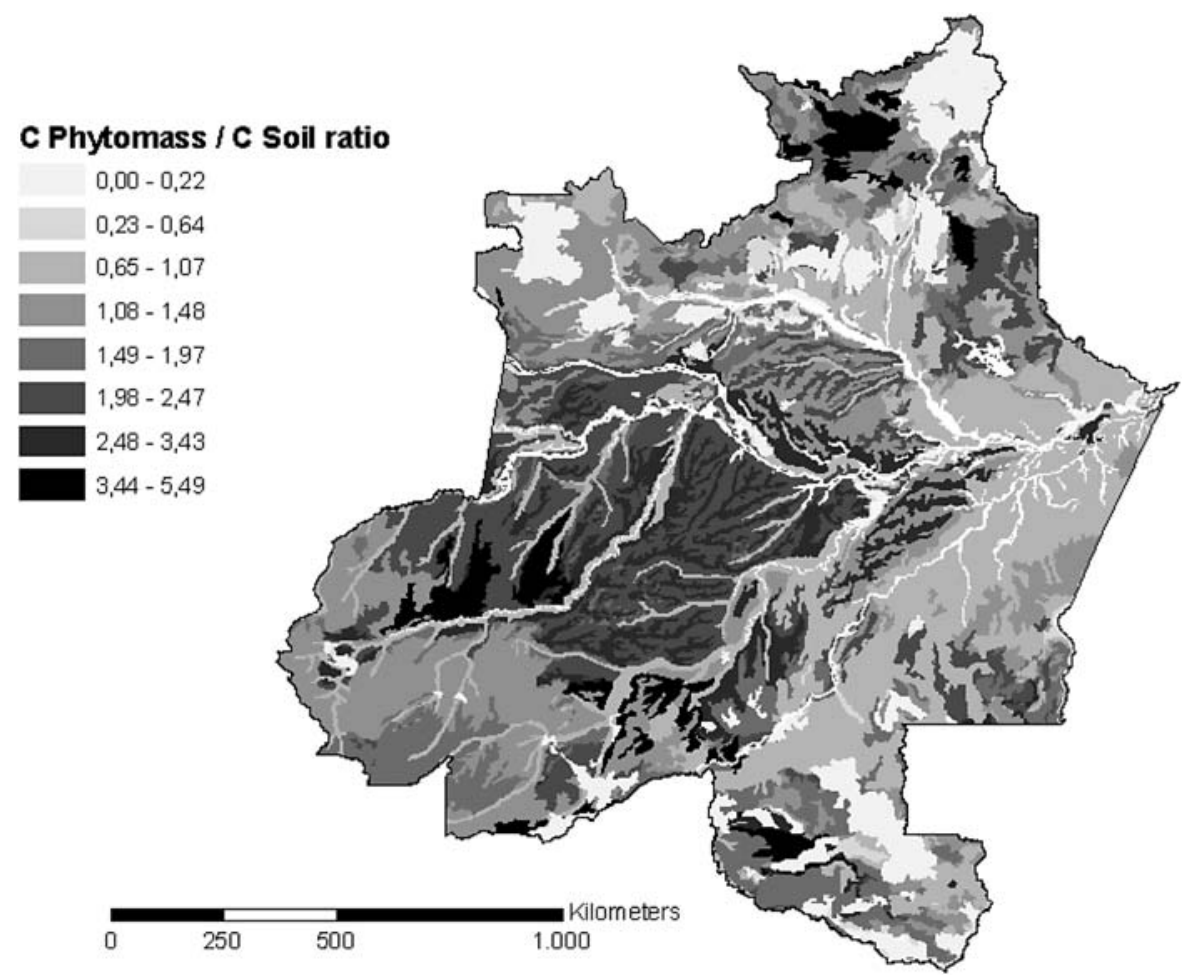


Fig. 6 Ratio between total of carbon in soil divided by rainfall in Western Amazonia

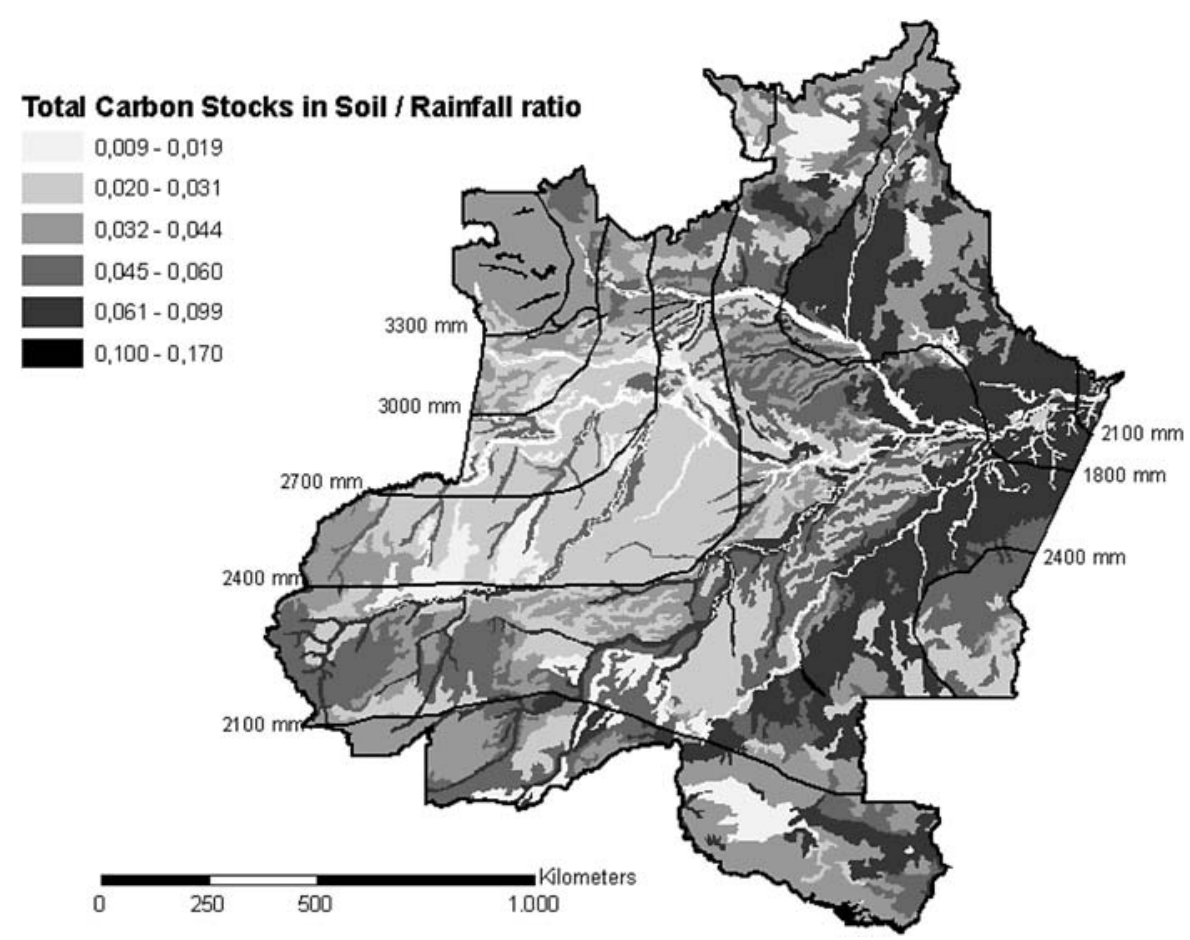

Relationship between rainfall and total soil carbon

(Al-rich) hydromorphic Plinthosol, under rain forest of primary sucession, in which $\mathrm{C}$ has not been fully incorporated. The same trend is observed in the shallower soils of the highlands pedo-zones of Roraima and Rondonia.

Figure 6 shows a climatic index of $\mathrm{C}$, expressed as the ratio between total soil carbon and mean rainfall, for
Fig. 7 Ratio between aboveground phytomass (vegetation) and rainfall in Western Amazonia

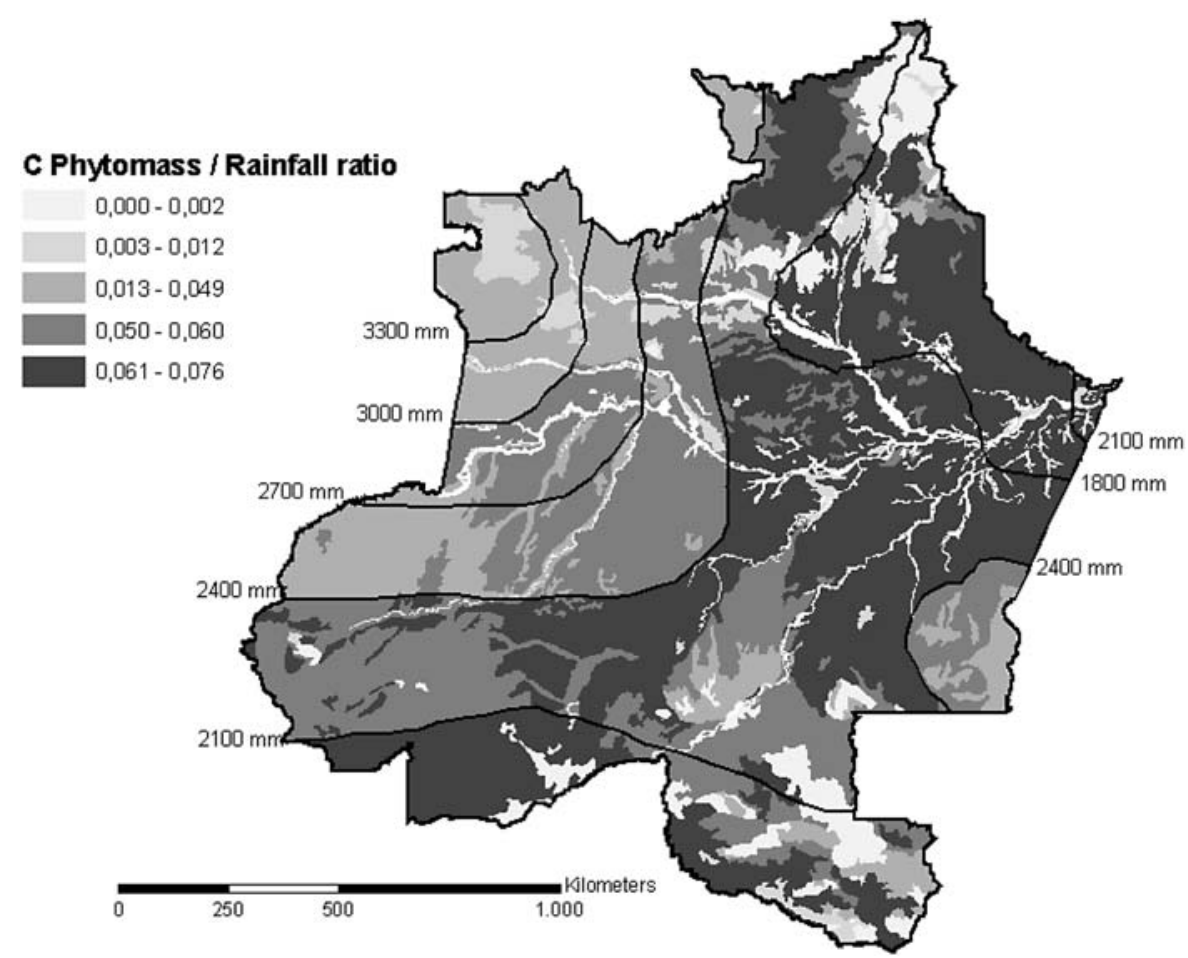


Fig. 8 Amounts of the $\mathrm{C}$ in subsurface horizons in Western Amazonia soils

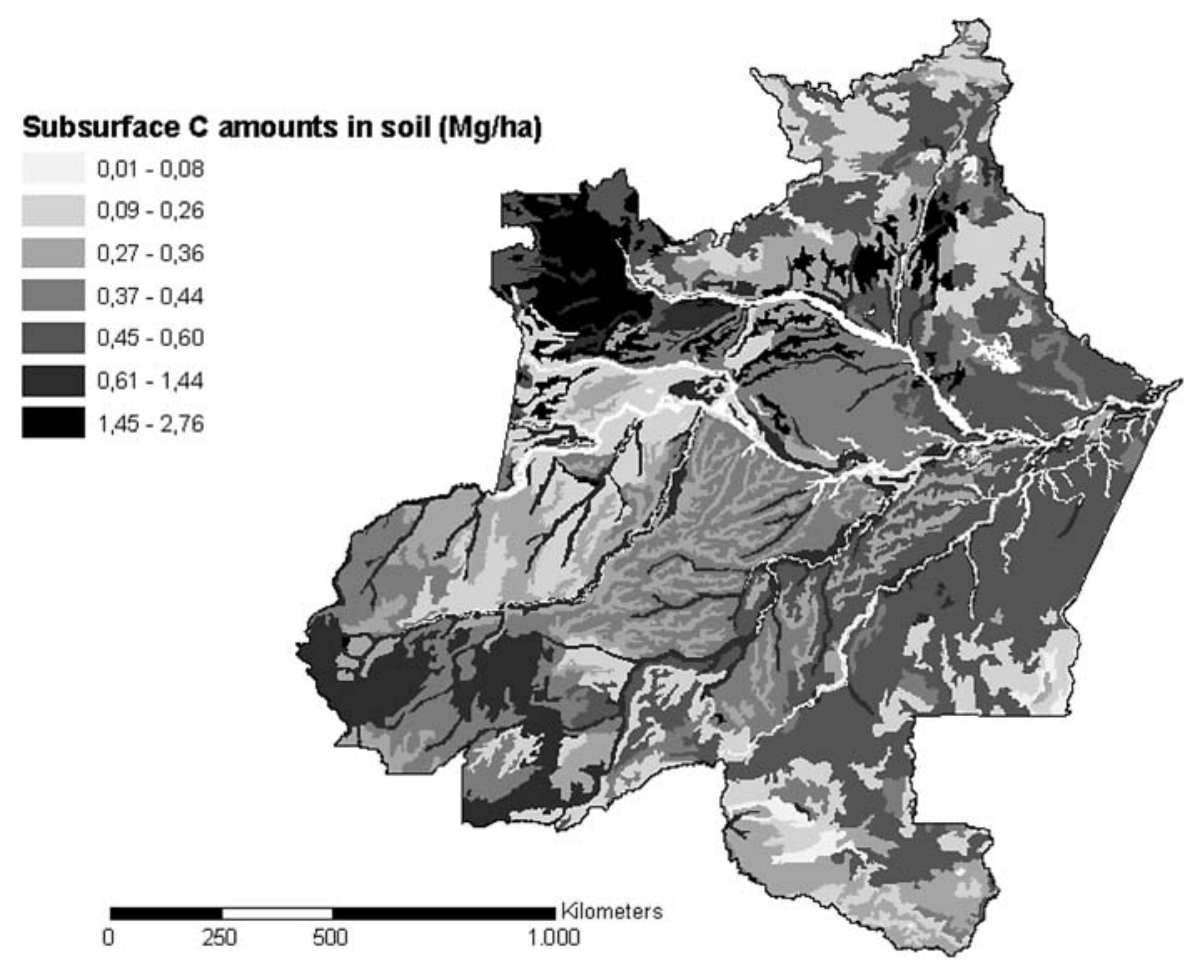

each pedo-zone. For a given rainfall, areas dominated by deeply weathered Latosols have a pattern of higher indexes (Tertiary Plateau pedo-zone), compared with shallower soils from the upper Amazon pedo-zones, west of Madeira and Negro rivers; also, scattered areas of Latosols in Rondonia pedo-zone also show the same trend. This is consistent with a greater carbon sequestration in these Latosols, compared with
Fig. 9 Ratio between subsurface $\mathrm{C}$ stocks and rainfall in Western Amazonia

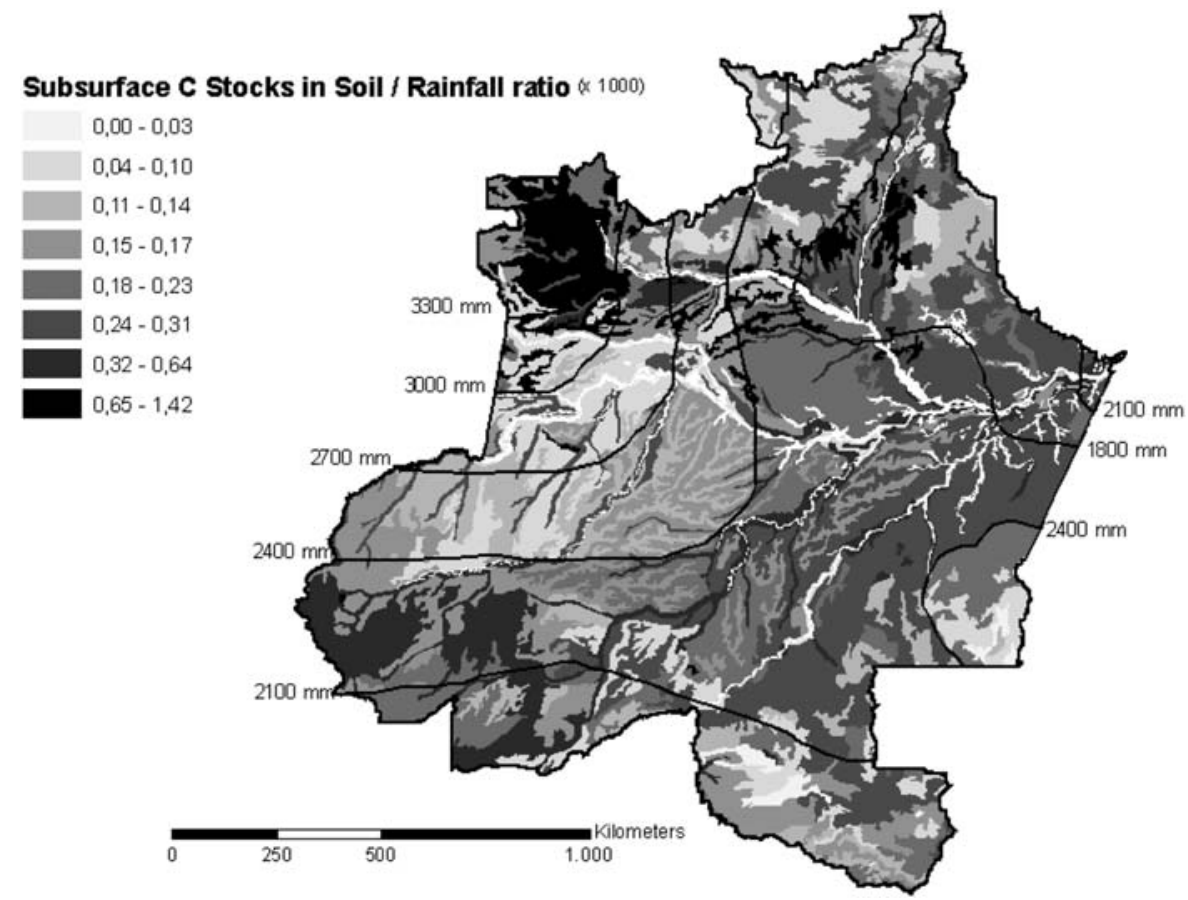


all other soil classes. This is attributed to a much deeper incorporation of carbon in these highly pedobioturbated, generally clayey soils (Schaefer 2001). This highlights the importance of biological activity for the turnover of carbon in Amazonia.

Aboveground carbon and rainfall

To best illustrate the inverse relation between plant biomass and rainfall in Amazonia, Fig. 7 shows the calculated ratio between aboveground phytomass (vegetation) and rainfall, using general climatic information; it is clearly observed a steady reduction of biomass following the climatic east-west gradient of increasing rainfall. Therefore, greater rainfall (exceeding 2,400 $\mathrm{mm} /$ year), associated with greater chemical leaching, sandy textures and wet-equatorial lowland surfaces, have the lowest $\mathrm{C}$ biomass production; this is, in turn, associated with soils in which $\mathrm{C}$ is being lost from the topsoil down to the spodic horizons, meaning effective $\mathrm{C}$ export from the natural ecosystem. This is illustrated by the widespread black rivers (tea-like) draining the Negro basin.

It should be emphasized that the abrupt lines showed in Fig. 7 are, in fact, artifacts of superimposed isoiets on a rasterized map of aboveground biomass. However, it is possible to observe a clear trend of $\mathrm{C}$ losses in the wetter, lowlands of western Amazonia, consistent with subsurface $\mathrm{C}$ amounts (Fig. 8) and the calculated ratio between subsurface $\mathrm{C}$ stocks and rainfall (Fig. 9).

\section{Conclusions}

The $\mathrm{C}$ stocks in Western Amazonia soils are extremely variable. Total $\mathrm{C}$ stocks are higher in the high-fertility Acre pedo-zone, where 2:1 clays with high cationic exchangeable capacity dominate, and in the Negro basin pedo-zone, where carbon is mobile, being either illuviated down the profile or actively lost from soil through extreme podzolization and arenization. High $\mathrm{C}$ aboveground biomass/C soil ratios are observed in the Javari-Juruá-Purus lowlands pedo-zone, where young Al-rich hydromorphic Plinthosols are found, and on the shallower soils from the highlands pedo-zones of Roraima and Rondonia.

Zones where deeply weathered Latosols dominate (Tertiary Plateau pedo-zone) have a pattern of greater
C sequestration, compared with shallower soils from the upper Amazon, west of Madeira and Negro rivers. This was attributed to deeper incorporation of carbon in these clayey and highly pedo-bioturbated soils.

There is an inverse relation between plant biomass and rainfall in Amazonia, observed by calculated ratio between aboveground phytomass (vegetation) and rainfall, showing a steady reduction of biomass following the climatic east-west gradient of increasing rainfall. Thus, rainfall greater than 2,400 $\mathrm{mm} /$ year in western Amazonia, associated with higher chemical leaching, sandy textures and wet-equatorial lowland surfaces, have the lowest $\mathrm{C}$ production; in these podzolized soils, $\mathrm{C}$ is moving from the topsoil down to the spodic horizons, meaning effective $\mathrm{C}$ export from the natural ecosystem.

The results highlight the need for refining soil data at an appropriate scale, when dealing with $\mathrm{C}$ stocks calculations for tropical areas such as Amazonia. There is an enormous risk of misinterpreting $\mathrm{C}$ stocks and in Amazonia when such great variability of pedological cover is not taken into account.

\section{References}

Andrade, F. V., Schaefer, C. E. G. R., Corrêa, M. L. T., \& Mendonça, E. S. (2004). Carbon stocks in Brazilian latosols (oxisols) from different morphoclimatic regions and management systems. Communications in Soil Science and Plant Analysis, New York, 15-16, 2125-2136.

Barbosa, R. I., \& Fearnside, P. M. (1999). Incêndios na Amazônia Brasileira: estimativa da emissão de Gases do Efeito Estufa pela Queimada de Deferentes Ecossistemas de Roraima na Passagem do evento "El Nino" (1997/98). Acta Amazônica, 29(4), Dez.

Bernoux, M. (1998). Conteúdo de carbono dos solos da Amazônia ocidental e mudanças decorrentes da conversão da floresta em pastagens. Piracicaba, 98 p. Tese (Doutorado)-Centro de Energia Nuclear na Agricultura, Universidade de São Paulo.

Bernoux, M., Arrouays, D., Cerri, C., Volkoff, B., \& Jolivet, C. (1998). Bulk densities of Brazilian Amazon soils related to other soil properties. Soil Science Society of America Journal, 62(3), 743-749.

Brasil. (1975a). Folha SB. 21 Tapajós; geologia, geomorfologia, pedologia, vegetação e uso potencial da terra, $418 \mathrm{pp}$. Rio de Janeiro: Ministério das Minas e Energia. (Levantamento dos Recursos Naturais, 7).

Brasil. (1975b). Folha NA. 20 Boa Vista e parte das Folhas NA. 21 Tumucumaque, NB. 20 Roraima e NB. 21; geologia, geomorfologia, pedologia, vegetação e uso potencial da terra, 428 pp. Rio de Janeiro: Ministério das Minas e Energia. (Levantamento dos Recursos Naturais, 8). 
Brasil. (1975c). Folha NA. 21 Tumucumaque e parte da Folha NB. 21; geologia, geomorfologia, pedologia, vegetação e uso potencial da terra, 370 pp. Rio de Janeiro: Ministério das Minas e Energia. (Levantamento dos Recursos Naturais, 9).

Brasil. (1976a). Folhas SC. 19 Rio Branco; geologia, geomorfologia, pedologia, vegetação e uso potencial da terra, 464 pp. Rio de Janeiro: Ministério das Minas e Energia. (Levantamento de Recursos Naturais, 12).

Brasil. (1976b). Folha SA. 21 Santarém; geologia, geomorfologia, pedologia, vegetação e uso potencial da terra, 522 pp. Rio de Janeiro: Ministério das Minas e Energia. (Levantamento dos Recursos Naturais, 10).

Brasil. (1976c). Folha NA. 19 Pico da Neblina; geologia, geomorfologia, pedologia, vegetação e uso potencial da terra, $380 \mathrm{pp}$. Rio de Janeiro: Ministério das Minas e Energia. (Levantamento dos Recursos Naturais, 11).

Brasil. (1977a). Folhas SB/SC. 18 Javari/Contamana; geologia, geomorfologia, pedologia, vegetação e uso potencial da terra, 420 pp. Rio de Janeiro: Ministério das Minas e Energia. (Levantamento de Recursos Naturais, 13).

Brasil. (1977b). Folha SA. 19 Içá; geologia, geomorfologia, pedologia, vegetação e uso potencial da terra, $452 \mathrm{pp}$. Rio de Janeiro: Ministério das Minas e Energia. (Levantamento dos Recursos Naturais, 14).

Brasil. (1977c). Folha SB. 19 Juruá; geologia, geomorfologia, pedologia, vegetação e uso potencial da terra, $436 \mathrm{pp}$. Rio de Janeiro: Ministério das Minas e Energia. (Levantamento dos Recursos Naturais, 15).

Brasil. (1978a). Folha SB. Purus; geologia, geomorfologia, pedologia, vegetação e uso potencial da terra, $566 \mathrm{pp}$. Rio de Janeiro: Ministério das Minas e Energia. (Levantamento dos Recursos Naturais, 17).

Brasil. (1978b). Folha AS. 20 Manaus; geologia, geomorfologia, pedologia, vegetação e uso potencial da terra, $628 \mathrm{pp}$. Rio de Janeiro: Ministério das Minas e Energia. (Levantamento dos Recursos Naturais, 18)

Brasil. (1978c). Folha SC. 20 Porto Velho; geologia, geomorfologia, pedologia, vegetação e uso potencial da terra, 668 pp. Rio de Janeiro: Ministério das Minas e Energia. (Levantamento dos Recursos Naturais, 16).

Brasil. (1979). Folha SD. 20 Guaporé; geologia, geomorfologia, pedologia, vegetação e uso potencial da terra, 368 pp. Rio de Janeiro: Ministério das Minas e Energia. (Levantamento dos Recursos Naturais, 19).

Brasil. (2004). Ministério da Ciência e Tecnologia. Secretaria de Programa de Pesquisa e Desenvolvimento. Coordenação Geral de Mudanças Globais de Clima. Emissões e Remoções de Dióxido de Carbono por Conversão de Florestas e Abandono de Terras Cultivadas.

Brown, S. (1986). Estimating biomass and biomass change of tropical forests: A primer. FAO Forestry Paper 134. Rome: Food and Agriculture Organization of the United Nations.
Brown, S., \& Lugo, A. (1992). Aboveground biomass estimates for tropical moist forests of the Brazilian Amazon. Interciencia, 17(1), 8-18.

Cummings, D. L., Kauffman, J. B., Perry, D. A., \& Hughes, R. F. (2002). Aboveground biomass and structure of rainforests in the Southwestern Brazilian Amazon. Forest Ecology and Management, 163, 293-307.

EMBRAPA. Empresa Brasileira de Pesquisa Agropecuária. Retrieved June 19, 2007, from http://200.20.158.13/website/ pub/brasil_solos.

EMBRAPA. Empresa Brasileira de Pesquisa Agropecuária. Sistema Brasileiro de Classificação de Solos. Brasília: EMBRAPA, 1999. 412p.

Fearnside, P. M. (1992). Greenhouse gas emissions from deforestation in Brazilian Amazon. Carbon emission and sequestration in forests: Case studies from developing countries, volume 2. LBL-32758, UC-402, 73 pp. Berkeley: Climate Change Division, Environmental Protection Agency, Washington, DC \& Energy and Environmental Division, Lawrence Berkeley Laboratory (LBL), University of California (UC).

Fearnside, P. M. (2000). Greenhouse gas emission from land use change in Brazil's Amazon region. In R. Lal, J. M. Kimble, \& B. A. Stewart (Eds.), Global climate change and tropical ecosystems. Advances in soil science (pp. 231-249). Boca Raton: CRC Press.

Fearnside, P. M., \& Guimarães, W. M. (1996). Carbon uptake by secondary forests in Brazilian Amazonia. Forest Ecology and Management, 80, 35-46.

Higuchi, N., Santos, J. M., Imanaga, M., \& Yoshida, S. (1994). Aboveground biomass estimate for Amazonian dense tropical moist forests. Memoirs of the Faculty of Agriculture, Kagoshima, 30(39), 43-54.

Houghton, J. T., Meira Filho, L. G., Lim, B., Treanton, K., Mamaty, I., Bonduki, Y., et al. (1997). Revised 1996 IPCC guidelines for national greenhouse gas inventories: Reference manual. London: IPCC/OECD/IEA.

IBGE. (1988). Instituto Brasileiro de Geografia e Estatística. Mapa de Vegetação do Brasil. $1^{a}$ Edição: Rio de Janeiro, RJ.

INMET. Instituto Nacional de Meteorologia. Retrieved June 19, 2007, from http://www.inmet.gov.br/html/clima.php.

Montagnini, E., \& Porras, C. (1998). Evaluation the role of plantations as carbon sinks: An example of an integrative approach from the humid tropics. Environment \& Management, 117, 149-167.

Schaefer, C. E. R. G. (2001). Brazilian latosols and their B horizon microstructure as long-term biotic constructs. Australian Journal of Soil Research, 39, 909-926.

Walkley, A., \& Black, I. A. (1934). An examination of the degtjareff method for determining soil organic matter and a proposed modification of the chromic acid tritation method. Soil Science, 37, 29-38. 